\title{
On The Trail of Southesk
}

By Rose McLaughlin, Indian Head

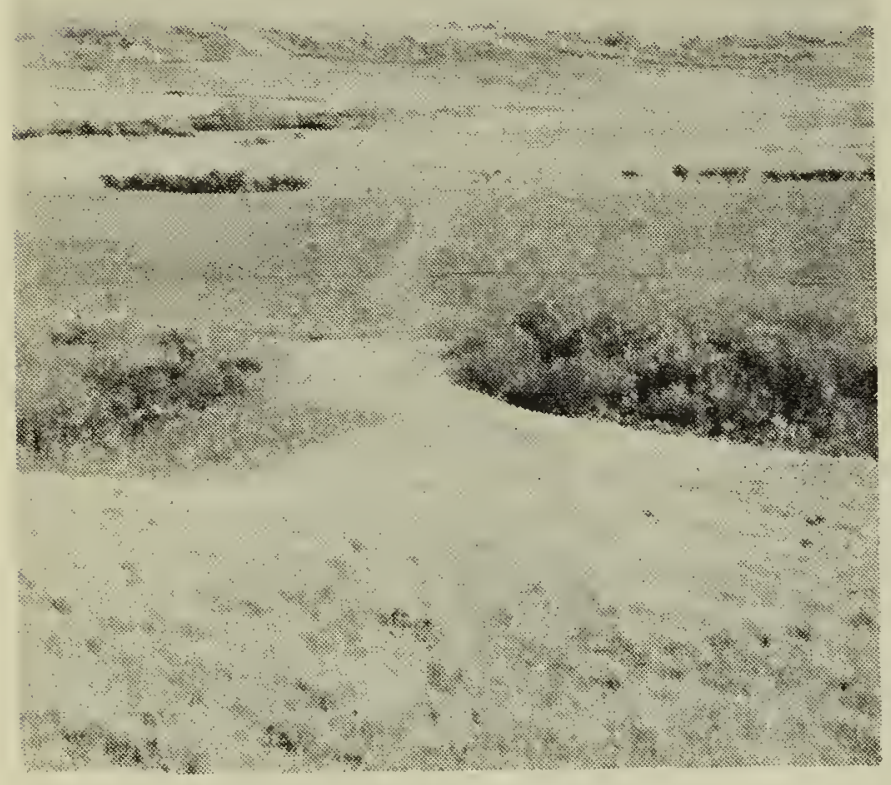

Ninety-nine years ago a young Scottish lord set out $\mathrm{c} n$ a hunting trip into the Canadian Northwest, planning to go as far as the elbow of the South Saskatchewan river, but in the end penetrating the outer bastions of the Rockies. It was in the spring of 1859 that the Earl of Southesk, weary of civilization, ailing in health, and, who knows, maybe crossed in love, made his way in the august company of Sir George Simpson, then governor of the Hudson Bay Company, from. Montreal to Fort Garry where he equipped a party of seven men for his memorable trek, including among his supplies a volume of Shakespeare, a copy of Richardson's Fauna Boreali Americana, and an india rubber bathtub.

Taking the Winnipeg-Old Wives' trail, Southesk's party duly camped on the night of July 1 at Great Creek, now known as Red Fox coulee, some ten miles southeast of the present town of Indian Head; and on the following day travelled via Deep Lake and the Squirrel Hills-wellknown landmarks both-to the old Qu'Appelle Fort where they made camp for the week-end of July 2-3.

Thus it was that a tour of the historic sites and trails of the district of Indian Head, organized by a committee in the Squirrel Hills S.D. and conducted by Carl Pearen. long-time resident there, should inevitably end in a fascinating jaunt into the past along the trail of Southesk.

Foregathering at the pavilion of the forestry farm at 10 a.m., Saturday, October 4, local people and interested guests from Regina, Moose Jaw, Yorkton and smaller towns nearby spent an informal hour browsing and chatting over $\mathrm{Mr}$. Pearen's collection of maps. The morning ended with a tour of points of interest closer in-the cairn to the Territorial Grain Growers, the bishop's court built by Lord Brassey during his brief but gigantic farm venture in the eighties, the Experimental Farm with its marker to commemorate the work of the first superintendent, Angus. McKay.

But all this was prelude, as evidenced by the augmented crowd which signed the register after lunch. Names of outstanding interest included Mrs. Clipsham and Mrs. Young of Regina, secretary and treasurer respectively of the Saskatchewan historical and folklore society; George IMcLeod of Fort Qu'Appelle who collects Indian folklore and folksongs; and Bruce Knox, president of the Regina natural history society. Upwards of 50 adults and a score or more of youngsters were packed into the cars which startec. out after a briefing by $\mathrm{Mr}$. Pearen on the route to be followed.

Ten miles and a stubble field away the motorcaide lolloped to a halt on the brow of Red Fox coulee where Southesk's party camped on that long-ago first of July. Mr. Pearen pointed out to us the shadowy trace of the old trail running across the cultivated floor of the broad valley and up the grassy slope beyond.

Driving west for several miles we came to Deep Lake, Southesk's "Lake of the Valley," which they reached just after breakfast on the second. Southesk, who had an eye for beauty, writes of the virgin prairie in this region:

"Flowers of the gayest colors enlivened the landscape-small tiger 
lilies and roises, blue-bells and white strawberry blossoms. Sometimes acres and acres were covered with intermingled masses of the orange lily and the pendulous blue-bell, the whole of them so short of stem that the glory of the flowers combined with the rich greenness of their leaves and it seemed as if a vast oriental carpet had been thrown upon the plain."

To us the autumn scene set amid fruitful fields was equally lovely. The gold of wild poplars on the slopes of the ravines mingled with the richer tints of chokecherry, saskatoon and dogwood, the leaves of the brier rose glowed jewel-like against the sun. and right below us, by the water's edge lay a scrap of pasture, vividly, tenderly green. The lake's surface, dark and smooth as polished wood, mirrored floating ducks and flying gulls and somberly reflected the glory of the hillsides. As if at a curtain call, and to the great delighi oi the children, two deer appeared, running down into the ravine and losing themselves among the bushes. (These were the white-tailed deer or jumper and not the cabree or pronghorned antelope which Southesk encountered in this region.)

Following, literally, the trail of Southesk we skirted the lake, pausing at the north end where, 75 years ago, a water wheel lifted water from the lake into a creek which emptied into the C.P.R. dam some miles to the north. Continuing west towards the Squirrel Hills we paused twice on the way-once by a crumbling stone foundation which is all that remains of St. Chad's Anglican Church built on this trail in the eighties, and once at Sunny South, an old stone school built in 1889 and still in use. (It was here that we saw a flock of migrating crows following trails far more ancient than ours, no doubt.)

We reached the summit of the Squirrel Hills by a long, rough drive through bluffy, unbroken pasture, our cars in their unwonted surroundings looking like lumbering prehistoric monsters. How lightly Southesk must have skimmed these slopes on his tough little pony, Wawpooss! One sees him in fancy against the skyine in his fringed buckskin shirt and high white American hat, gazing at "an extensive view over a level prairie bounded by a stretch of woodland in the distance. No life was visible except a solitary wolfor fox-running across the prairie."

From this hilltop oldtimer Will Liggett whose farm lies one mile east pointed out to us the vestiges of the early triail. here through a field, there through a gap in the poplars, and drew our attenticn also to the region of swamps and springs just northeast of us whence Irdian Head gets its excellent waier supply. Mr. Pearen explained tiat the pioneer trails followed these water holes.

Here Southesk's diary reads, "We halted for dinner not far from the Qu'Appelle Fort," and Mr. Pearen now took us to a field a mile or more north of the Squirrel Hills which he believes to be the site of that fort, which was in use from 1855 to 1864 . Evidence of occupation has been found here, though not as yet the abundance of chimney. clay and foundations which mark a site some miles further on that is more commonly held to be the liccation of the Qu'Appelle Fort.

This second site we visited too, on rich farm land owned by the Leibel brothers, and near the "long point" of Little Long Lake where the Old Wives and Wood Mountain trails crosis. Mr. Pearen identifies this site with the fort of "certiain free traders" which southesk writes of as operating somewhere in this vicinity.

Be the Qu'Appelle Fort where it may, Southesk's party camped there over Sunday, visiting the superintendent, Mr. Cardinal, and entertaining some wandering Objiways. Sunday evening the earl sat in the door of his tent watching the splendor of the sunset and reading "Troilus and Cressida."

Monday morning they were on their way again. One pictures them, in Southesk's words, "topping the crest of a low hill, ribbons streaming, guns swaying, whips flashing, gay colors sparkling in the sun-all life, dash, rattle, and glitter. . . .'

And so reluctantly we took our leave of the gallant party in whose company we had spent a momorable afternoon. 